\title{
Crossing Disciplinary Boundaries: Labour History and Museum Studies
}

\section{Bobbie Oliver and Andrew Reeves}

The idea for a thematic issue of Labour History examining ways in which working culture is - or is not - interpreted in Australian museums and galleries arose out of the perceived absence of such material among labour history sources. Attempts to find this type of critique for teaching undergraduate students in a Cultural Heritage Studies course at Curtin University and involvement in a campaign to establish a rail heritage centre on the Westrail Workshops site at Midland, WA, were motivators. We were interested in crossing disciplinary boundaries between labour history and museum studies to ascertain the extent to which other scholars had considered the interpretation of working culture in a museum or gallery setting.

Since the publication of John Rickard and Peter Spearritt's examination of public history over a decade ago, ${ }^{1}$ there has been an increasing awareness of the historical and heritage value of industrial sites - Spearritt's paper on Woolloomooloo's Finger Wharf in the above volume being one example - but what of working culture itself? 'Halls of Fame' around the country have tended to emphasise the role of powerful, well-known individuals such as Sidney Kidman, the 'Cattle King', or generic types of workers (the miner, the prospector, the stockman, the timber cutter). Robyn Trotter has shown that, in the case of the Stockman's Hall of Fame - where the choice of the singular in the title is interesting in itself - it was very easy to 'valoris[e] ... the "great man" of the outback' and difficult to move beyond stereotypes of 'women, Aboriginal station workers, Afghan muleteers, hawkers, mail carriers and even travelling entertainers ....' ${ }^{2}$

Why should the interpretation of working culture on industrial sites and in other contexts be of consequence to labour historians? In making forays into the world of the curator, are we not departing from our own comfort zones and fields of expertise? Perhaps so, but there are many good reasons why we should be proactive in continuing to broaden the definition of 'labour history'. Firstly, we could perhaps reflect profitably upon why a discipline, which, at the end of the twentieth century, in the words of Irving and Scalmer, is 'a popular, collective, democratic, regional, and political form of history-writing [which has] grown out of the popular history written by labour activists earlier in the century'3 has been so inadequately translated into the curatorial field. Beyond the random display of union banners - often for their 'artistic' or 'cultural' value as much as examples of working-class struggle, solidarity and pride - how often have museum displays attempted to represent the historic concerns and realities of organised working people? The answer is: not often. Work is impersonally defined as technology; machines are as conspicuous as working people are absent.

The otherwise excellent STEAM Museum at Swindon (UK) provides an example of the down-playing of the industrial experience. While displays emphasise different classes, roles and skills of the workers, and the Museum's effort to aurally reproduce industrial working conditions provides the visitor with a faint semblance of noise levels in a real, working factory, there is a deafening silence on industrial organisation 
or union activity. ${ }^{4}$ Why is this so? Is it because industrial organisation is perceived as being socially divisive?

With far greater numbers of people accessing exhibitions, displays and the visual and electronic media, in preference to the written word, labour historians cannot continue to be complaisant about the value of published histories and journal articles in informing future generations of their industrial past. Consequently, further academic debate is urgently needed on the manner, methods and aims of interpreting working culture to increasingly diverse audiences. There is an on-going need for practitioners of different disciplines to develop and maintain dialogues with one another. Internationally, the task has commenced. Museum members of the European-based Worklab network have commenced a number of collaborative projects addressing the nature of work, changing work practices, women, immigration and workers' movements, as well as issues relating to the depiction of working-class individuals and political organisations. In these projects, as in geography, Australia is placed on the margin.

This issue of Labour History attempts such a dialogue by publishing papers from practising curatorial staff as well as historians in academe. The following are some of the issues raised in this collection of papers. How successful have attempts been to interpret various types of working experience in large industrial factories (such as Eveleigh Railway Workshops in NSW or the Sunshine Harvester Factory in Victoria)? How might curators encompass the breadth and variety of experiences that should be reflected in a display of 'working women'? Is it possible to overcome cultural aversions in representing such marginalised groups as prostitutes? Lastly, how might one view afresh such 'cultural icons' as the Eureka Stockade and present a story that people think they are familiar with in a new and challenging way?

In assessing the public's response to private 'brothel tours' and 'sex industry museums' such Langtrees in Kalgoorlie, Simon Adams and Rae Frances challenge museums to re-think the ways they have portrayed prostitution - or, in many cases, the total absence of any portrayal. Brian Crozier and Helen Gregory discuss the challenges of anticipating their audience and finding fresh and interesting ways of 'celebrat[ing] the lives, work and contributions of women past and present who have helped to build our nation'. In the context of preserving 'intangible aspects' of working culture at the Eveleigh Railway Workshops site, Lucy Taksa asks whether we have actually progressed far since the Whitlam Government established a framework for heritage policies in the 1970s. She concludes that 'emphasis on the conservation of material culture, without adequate attention to and funding for interpretation has concealed the workers' experiences beneath Eveleigh's tangible heritage'. At the Sunshine Harvester Works in Victoria, 'only a few sad remnants of the factory remain'. Without buildings and objects to create the tensions between representation of built fabric and machinery, on the one hand, and 'intangible aspects of culture', on the other, Charles Fahey, John Lack and Liza Dale-Hallett discuss the challenges of representing the lives and experiences of the workers through archival film footage, photographs and other materials. It is worth noting that some of the materials that form the basis of new representations and interpretations of the working lives of Sunshine Harvester employees were themselves miraculously salvaged from the tip by some of those same employees. The Midland (WA) Railway Workshops project - in which one of the co-editors of this thematic, Bobbie Oliver, 
is involved - has similar stories of employees rescuing material from skips after the government authority abdicated its responsibility by not ensuring that records were appropriately disposed of through the State Record Office. Consequently, one has to ask how much similar material has been destroyed?

In the concluding paper of the thematic section, Anne Beggs Sunter focuses on the public interpretation of the Eureka Stockade in a new Centre at Ballarat. In particular, she asks, how can a number of conflicting versions of a well-known story be accommodated? Her question has connotations for all historians in the field of working culture where fact merges with myth and legend. When an oral history project commenced at the Midland Railway Workshops (referred to above), past employees were encouraged to tell 'good stories' and to describe 'characters' and 'personalities' with whom they had worked. While many 'characters' came to light, perhaps surprisingly few 'loomed large'.

Regrettably, time constraints did not permit any of the research team to prepare a paper on the Westrail Workshops at Midland, a site where substantial heritagelisted buildings are still awaiting restoration or redevelopment. For this reason, the balance of this Introduction will discuss a number of the issues relevant to the papers in this edition of Labour History that have arisen in the Midland Workshops History Project. The site presents an interesting contrast with the Sunshine Harvester Works, the Eveleigh Railway Workshops and the Ipswich Railway Workshops - all sites of former large industrial complexes. Of these, Ipswich has been the most 'successful' in terms of retaining something of the original 'factory streetscape' and providing space for the continuing practice of trade skills as well as establishing a railway museum. ${ }^{5}$

During this issue's preparation for publication, a team of consultants was preparing for the Midland site's management body, the Midland Redevelopment Authority, a study of the feasibility of establishing a rail heritage centre in one or several buildings on the Workshops site. As we await the outcome of the study, those of us who are involved with the site in various ways are alert for examples of 'best practice' in other industrial museums around the world. When we began the oral history project in 1998, we developed a series of principles to undergird and guide our practice. These included, firstly, the decision that the Project would be a collaboration between trained academic historians, union officials, and workers in all aspects of the industry, thus exploiting and adding to a rich tradition of community and popular history within the union movement. Secondly, a principle aim would be to enable the workers to tell their own stories, rather than majoring on industrial process and progress. This would involve discovering (mainly through interviews) the daily experiences of the employees and their families. Thirdly, the project would be a vehicle for informed debate about the preservation of the site and of industrial heritage in general. ${ }^{6}$ If these principles were sound for the oral history project could they be applied to the development of a rail heritage centre?

The Midland Railway Workshops site is currently managed by the Midland Redevelopment Authority (MRA), a government authority, which has a 15-year tenure in which to redevelop the area (now known as Helena Precinct because of its proximity to the Helena River). The site-including buildings, plant and equipment, roads, railway tracks, open spaces and landscape elements as defined in the Conservation Plan - has been assessed by the Heritage Council of WA as having heritage significance because of its current (largely unaltered) condition and its 
industrial, economic, social and political role in the life of Western Australia over the twentieth century. Eight buildings have been identified as having exceptional heritage significance. These are the three main blocks, and additions such as the flagpole and the Peace Memorial; the Chief Mechanical Engineer's Office, (currently occupied by TAFE); the Railway Institute Building, (currently occupied by the MRA); the Pattern Shop; the Power House, and the Old Tarpaulin Shop. All of these buildings were constructed in 1904 and most were added to c 1910-12. Other buildings, including the Foundry $(1904,1912)$ and the Gate Keeper's Office (1924), are regarded as being of 'considerable significance'. 7

The Heritage Strategy (2002) states that all site features of exceptional or considerable significance should be retained and preserved, including certain open spaces. In other words, it should be possible to walk through the re-developed site and recognise the former use of the buildings, and the 'streetscape' should not be significantly altered. Beyond that, the 'streetscape' should retain an authentic industrial feel - not one that is manufactured by mounting a few pieces of railway hardware on a wall and given a name that has no significance to the site's past. Ideally, therefore, the whole site is the terrain for such interpretation: the whole sight needs to recover the sights, sounds, smells and noises that characterised the workshops 'at work'. Far from limiting the vision of what can be done at Midland to a building with a traditional museum layout, it needs to create strategies by which the site becomes a living, breathing workshop environment again. Principles put into practice elsewhere in Australia or overseas could serve as an indicator of what might or might not succeed at Midland.

What then might be the key to this strategy? Firstly, the site is a place of many stories. How can those stories be preserved in the public domain, so that they remain evident in the fabric and purposes of the site? Two examples serve to illustrate the complexity of the problem. The Workshops was built to process steam locomotives from the time they entered for repair, through the stripping down and the replacement of parts, to the end of the line where they emerged as repaired engines. How can the story of that process be preserved? In Block 3 is an area where a row of lathes used to stand. It was called 'Red Square' because one of the lathes belonged to active Communist Jack Marks. Jack and his fellow Party members organised themselves so that they occupied a group of lathes in one spot in full view of the foreman's office. There, they used to disseminate Communist propaganda to anyone who was interested. Linked to the political activity of Red Square, is the site's most significant 'open space' in front of Blocks 1,2 and 3. The main features of this open space were numerous railway tracks which once ran to each of the main blocks, but which today all have been removed except for one line, and the still extant flagpole, famed as a gathering point for workers. Many stop work meetings took place, and political and industrial speeches were made at the flagpole. In the minds of many employees, the flagpole would be the focal point of the Workshops; while it had nothing to do with the technological processes of the site, and was built simply as a staff on which to fly the flag, it became central to issues of industrial management, and conciliation and arbitration. It was also a space that the workers claimed for themselves - their gathering point where they exercised the rights won for them by unions in the first half of the twentieth century and where, also, they defied the employer and discussed their grievances in his time. 
It was on this spot, too, that the workers learned of the fate of the Workshops when the closure was announced in 1993. So, the flag pole and the space surrounding it has developed many layers of meaning over the years, and these should be conveyed in any future interpretation of the site. Thus the project's aim to letting the workers tell their own stories might be realised in an interpretation of the flagpole and its vicinity.

So, people and their stories are the key to an interpretation strategy for the site, but the difficulty lies in how they are used and what ideas and possibilities they unlock. Using the example of Bootts Mill in Lowell, Massachusetts, which is designed as an interpretative experience but builds on industrial realities and consciously links them to present concerns and experience, interpreters could build on Midland's position as a cradle of industrialisation in Western Australia, with all the social implications that flow from that. The Workshops provides lateral links to other industries and to other areas of the state. Most, if not all, of Perth's early industrial sites have ceased functioning, but all have a few points in common, not the least that they provided a long standing point of entry for immigrants into the WA labour force and the paid economy. Linked with the workshop picnics, outings, competitions and sporting events, one can begin to create a picture of an economy and social life that defined early twentieth-century Perth and which could now provide a broader context in which to locate the workshops.

This concept could be given contemporary relevance by forming partnerships with a TAFE college to develop a training programme in the classic railway trades including the development and maintenance of an apprenticeship system. The range of skills and trades is vast: all varieties of engineering, boiler work, painting, decorating, coachwork and woodwork, moulding, leather and canvas work - the list is endless. None of these are extinct; many have transformed themselves and found new forms of expression. Midland could be developed for the focus for further training in these trades, as well as an outlet for their products. There are precedents in Australia and overseas. In the 1980s, the Cain State Government brought together a team of stonemasons to provide the necessary skills to refurbish and maintain Victoria's stock of nineteenth-century bluestone public buildings. This led to RMIT establishing a technical course in masonry, the training of a new generation of masons and the creation of a number of businesses. In that case, the built heritage of Melbourne provided the focus; Midland could provide a rail and tram equivalent. At the STEAM Museum (Swindon, UK) and at the Ipswich Workshops site in Queensland, workshops demonstrate the skills interpreted elsewhere in more traditional museum formats, such as exhibitions. Midland could be established as the national rail and tramway restoration workshops, a centre of excellence, undertaking work at Midland or in situ for the myriad of rail and tram societies that are now seeking to restore or refurbish engines and rolling stock for the community, tourist and heritage railways that one comes across everywhere.

Apart from the re-establishment of trade skills associated with the restoration of engines and rolling stock, the Midland site provides scope for workshops in a range of other trades and fine arts: painting, leather, metal and textile work. Some of these could become a joint venture, such as a banner workshop. Based on industrial traditions and linked to tertiary art programs, banner-making is a medium that has extended and redefined itself in the last 20 years. Such a program could both create 
and address a community need and purpose for banners: not just unions but community organisations, local government, public institutions, schools, banners to commemorate public events. Again, precedents are provided by the Melbourne Trades hall banner workshop and the Victorian Tapestry Workshop.

But building on skill is not the only direction. Clearly, opportunities exist to use a variety of display and entertainment devices to interpret the workshops and the history of its people. It would a relatively straightforward task to decide on a appropriate set of periods and events to deal with, but why not extend these to the social dimension of the workshops such as anti-war activities, the influence of world war, the introduction of women into the metal trades, strikes, Communism and laborism, politics in the workshops and its influence beyond Midland, multiculturalism, the 'private economy' of the workshops - private works, souvenirs and keepsakes. While the concept of the workshops themselves as a community is a useful device, the place of the workshops in a wider community shouldn't be neglected either. This is where the possibilities of Midland approach issues that mainstream museums have neglected or marginalised: ways of living; living standards; the balance (or imbalance) between working and domestic life. Midland provides both a good venue and the necessary reservoir of artefacts, people and stories.

At one remove is the issue of the relationship between people and technology. Contrary to the impression conveyed by orthodox interpretation, this is not just a matter of placing people and machines in some sort of economic relationship that is invariably represented as productive and not problematic in the least. And yet this relationship, and its attendant questions of who manages technology, who is in charge of the machines, of the labour process, of the working lives called into action by the industrial opportunities - goes to the very heart of the Midland workshops and any consideration of future planning.

The issues that moved the workshop and its people are still questions of urgency today. To address these in an open, reciprocal way - not overly didactic or determinist - is a challenge that few museums or heritage sites have accepted. Midland could serve as a balance sheet of industrialisation, of economic and social development but do so in a way that enriches the experience of visitors and provides new perspectives on the history of twentieth century Western Australia. Consequently, labour historians have a significant role to play in discourses on the public interpretation of industrial heritage and working culture. We hope that this issue of Labour History will not only contribute to this discourse but stimulate further debate by practitioners of labour history whether in academic or other institutions or more widely. We wish to thank the authors; the anonymous peer referees for their constructive comments, and Greg Patmore and Margaret Walters for their advice and support during the preparation of this issue. 


\section{Endnotes}

1. J. Rickard and P. Spearritt (eds), Packaging the Past? Public Histories, Australian Historical Studies, vol. 24, no. 96, April 1991.

2. R. Trotter, 'Pioneering the past: a study of the Stockman's Hall of Fame' in T. Bennett et al (eds), Celebrating the Nation: a Critical Study of Australia's Bicentenary, Allen \& Unwin, St Leonards, 1992, pp. 162-3.

3. T. Irving and S. Scalmer, 'Labour Historians as Labour Intellectuals: Generations and Crises' in D. Palmer, R. Shanahan \& M. Shanahan (eds), Australian Labour History Reconsidered, Australian Humanities Press, Parkside, SA, 1999, p. 238, emphasis in original.

4. Personal observation from a visit by B. Oliver to the STEAM Museum, Swindon, in July 2003.

5. Thom Blake and Andrew Moritz, 'From Moving Goods to Might and Muscle - the Development of the Workshops Rail Museum Queensland', paper presented at the Museums Australia National Conference, Perth 2003.

6. 'Some Principles underpinning the Midland Workshops History Project', unpublished document, c 1999.

7. Heritage and Conservation Professionals, Draft Heritage Strategy Midland Central Redevelopment Area, prepared for the Midland Redevelopment Authority, 2001, Strategy 1 Paper, p. 2. 